\title{
The Impact of Informal Cross-Border Trades on National Economic Development: "A Case Study of Nigerian Southern Borders"
}

\author{
Olakunle Olusola Ajayi \\ International School of Management (ISM), France \\ olakunleajayi@gmail.com
}

\begin{abstract}
Difference in factor endowment has necessitated the need for cross-border trade which involves people from two different countries trading items of value with each other and as such laws, rules, regulation and medium of exchange is needed for economic development to take place. This paper investigates the impact of informal crossborder trade on national economic development: A case study of Nigerian Southern Borders. The study made use of Yamene (1967) to ascertain the sample size as a total of one-hundred and one (101) population was targeted from six different professions. The qualitative research design and purposive sampling technique was applied in this research work as the study also utilized oral interview technique. The study made use of descriptive statistics, multiple regression and pearson product moment correlation coefficient analysis for the purpose of data analysis. The result of the analysis indicated a positive and significant relationship between cross-border trade and per capita income whereas a negative and insignificant relationship was identified between informal goods coming in and going out of the country.

Thus, the study recommends the following - fully integrated e-payment systems for duties, streamlined goods clearing systems, robust whistle blowing system tied to good reward system, frequent transfer of officers in and out of the border posts, enhanced compensation system for officers, adoption of incentive and regulatory policies by government to promote indigenous entrepreneurship and lastly, enhanced profiling system of duty payers for extension of discounts, rebates and waivers based on their transaction history from time to time.
\end{abstract}

Keywords: Import, Export, Fine, Border, Security.

DOI: $10.7176 / \mathrm{DCS} / 11-7-06$

Publication date:September 30th 2021

\subsection{Overview}

The difference in location and accessibility of natural resources/endowments has necessitated the need for international trade. This entails the movement of people, goods, and services from one country to another. The movement can be done via land, rail, air, or sea. The choice of movement is primarily dependent on the means available, commodity involved, urgency of delivery and the cost. Theories have it that international trade ought to aid technological advancement and bring about economic development. International trade is the exchange of product, capital and services across territories (UNCTAD,2019), following the laid down government regulatory framework (OECD, 2009). According to Samuelson and Nordhaus (2002) foreign trade is a system that enable a nation to have access to foreign capital, goods and services. It was recorded in the World Bank (2006) global economic prospect-that foreign trade contributes to sustainable, and equitable growth which overtime improves a nation's financial position and long-term economic gain.

The comparative advantage theory propounded by Ricardo in 1817 states the reasons why trade is necessary between countries. This theory added that wastage is reduced, cost of production is also reduced while the countries benefit from each other on the long run by reducing the duties imposed on goods imported and exported. Historically, Nigeria has strong trade ties with the countries that borders it at one point in time or the other. However, it has been observed over time that these bilateral ties are often threatened and weakened by different boundary issues as well as internal policies of successive governments.

Cross-border trade (CBT) can be defined as trade that involves two countries of which there is a given place called a border (this is a point/line/area that demarcates a country's geographical location from that of another and also demarcate the home country from a foreign country) via some statutory barricade such as a toll gate (this is usually a gate that cuts across or separates two countries or states, mostly manned by national customs officials who check entry/exit documents before passengers and/or goods can cross from one country to another). World Bank, (2010) define CBT as the transaction of legal goods between countries through official channels, Soderbaum and Taylor, (2008) pointed out that CBT encompasses trade that take place within a region's political, economic, administrative, and cultural value which could be either formal or informal as these cuts across all religion, ages and ethnic groups.

There are two kinds of activities that are legitimately carried out at these locations between parties in the two different countries, it is either the home country is importing, or the home country is exporting, and vice-versa. In 
a case where the home country is bringing in (importing) goods or commodities from the foreign country, it attracts a fee called import duty (this is a monetary fee that is levied on goods entering the country from a foreign country, usually denominated according to extant values attached and approved by the home country). Conversely, when the home country is taking goods (exporting) out of the home country, it attracts a legal fee called export duty (this is a monetary charge that is imposed on goods that leave a home country to a foreign country). It is important to note that in a situation whereby, the parties involved in transacting business are found to have committed some malpractices or do not have the required documentations to carry out legal transaction, the authority in charge levies them a fine (this is a charge that is levied on violations and/or criminal activities that are likely to occur) which serves as a control mechanism and punitive measure adopted by a country and it also helps the country to generate revenue.

People engage in trans-border crossing for various reasons which are not limited to social engagement, trade and tourism etc. especially through land borders because of the ease of crossing when all the relevant entry/exit documents are complete. The borders are however not devoid of issues between settlers at the border towns on both side of the divide, as well as the notorious activities of informal traders who devise several strategies to avoid paying the stipulated duties (import/export) or smuggling of contraband goods.

Formal cross border trade exists when parties involved in trade officially engage the codified interaction that governs trade between two or more countries (Soderbaum \&Taylor, 2008). Informal cross-border trade (ICBT) refers to the sum total of business transaction taking place across border boundary markets which are not recorded (CBN, 2016). Informal trade has been discovered to be a lucrative venture that provides short-term solutions to the unemployed and households as it creates jobs and welfare stability (Afrika \& Ajumbo, 2012; Kabira, 2006; Matsuyama, 2011; OECD, 2009; UNCTAD, 2011; Yusuff, 2014). The vast natural resources and abundant supply of labour in Nigeria made the country an international trading hub, and as such, there is need for various trade policies that will help in protecting local industries from external competitors.

Trade policy are rules and regulation that guide international trade between two nations and anyone who engages in such trade must comply with such rules and regulations (Yusuff, 2014). Nigeria's trade policy can be traced back to independence when the General Agreement on Tarif and Trade (GATT) of 1960 was signed which represents one the first policy that guides international trade in Nigeria followed by the Economic Community of West African State (ECOWAS) founded in year 1975 as it was established to promote co-operation and integration among member states. The Structural Adjustment Programme (SAP) of 1986 and West African Economic and Monetary Union (WAEMU) served as a cocktail of free-market economy and protectionism as its major objective was to diversify exports and liberalize imports. In the year 1990, Nigeria became a member of Trade Liberalization Scheme (TLS) and also became a member of World Trade Organization (WTO) in 1995 with the hope of achieving free trade with other member countries. In the same year, Nigeria signed the General Agreement on Trade in Service (GATS). The Customs and Excise Duty Management Act (CEMA) was implemented in the year 2004, this act helped in correcting the deficiencies identified with the Customs Duty Act of 1958 which gave customs officers the right to act on behalf of Nigeria in customs related matter. The African Growth and Opportunity Act (AGOA) which Nigeria became a member in year 2000 grants the country duty free access to about 40 sub-Saharan African Countries. The WTO agreement was rectified early 2017 in the same year Nigeria signed co-operation agreement with European Free Trade Area (EFTA). There are several other recent policies implemented such as the African Continental Free Trade Agreement (ACFTA) and others, all these policies are intended to stimulate economic development as the ineffectiveness of any one of these policies will intensify informal trade activities across borders.

Criminal activities are at its peak at Nigeria's borders, mostly in the Northern part of the country. These borders have been used by criminals, and smugglers to perpetuate their evil acts by using these borders originally designed to facilitate trade between neighboring countries for money laundering, illicit movement of arms (guns) and ammunition and smuggling of hard drug (cocaine, heroin, cannabis, etc.), goods and food products designated as contraband into the country (Adeola, \& Oluyemi, 2012; Babatola, 2015). Sunday, Oji and Okechukwu, (2014) discovered that the level at which the army and civilians lose their life as a result of the arms that are smuggled into the country is terrifying. Nigeria has four main border areas which are located in the Northern, Western, Eastern and Southern part of the country. Trading activities are performed along these borders by citizens of Nigeria and that of the boundary nation and cross-border trading is mostly the occupation of citizens living along the borders of most nations in Africa.

The borders have their peculiar issues such as innocent citizens being harassed frequently by officers (Police, Custom and Immigration) requesting for bribe and shady favours in the course of their duty at the borders. People cross the borders without having the necessary documentation, while the officials collect kick back (Adeyinka, 2014). All these are part of what cripples' national economic development in Nigeria as the resources available are not being rightly channeled into productive use because government expenditure on defense is on the increase, thereby negatively impacting availability of resources which is meant for other equally vital sectors of the economy. These vices also discourage and repel investors from investing in the economy. The insurgent activities 
that takes place within the towns, and states located around the borders contribute to the quantum of the migration of people on a yearly basis from Nigerian to neighboring countries.

The main purpose of this work is to investigate the implication of informal cross-border trades on national economic development in Nigeria, with a view to helping government and industry practitioners to understand the nature of informal cross border trade and the impact on national economic development. The objectives are as follows:

(i) To examine if cross-border trade increases per capita income in Nigeria.

(ii) To investigate if informal goods leaving the home country leads to economic development, and

(iii) To investigate if informal goods entering the home country leads to economic development. In the same manner, the research questions above have been formulated to proffer a better understanding of the impact of informal activities that take place at the South Eastern border of Nigeria on national economic development. Below are the questions:

i. Has cross-border trade led to an increase in the per capita income in Nigeria?

ii. Has informal goods leaving (exported) the home country led to economic development?

iii. Has informal goods entering (imported) into the home country led to economic development?

\subsection{Theoretical Review}

\subsubsection{Comparative Advantage/Cost Advantage Theory}

This theory was propounded by David Ricardo in 1817. This theory states that countries should produce goods that they have lower opportunity cost than other countries. This gives the home country the advantage to sell its product at a lower cost, making the trade- off favorable to the home country. The basic assumptions are as follows; the first is that there are only two countries which produce two commodities. Secondly, there is only one factor of production which is labour and there is also free trade between the two nations. Thirdly, there are two commodities and there is no monitoring transaction between the two countries. Fourthly, there is need for countries to produce commodities that they use less of labour to produce. In summary, countries should specialize in producing goods that they produce efficiently and buy the goods that they produce less efficiently.

\subsubsection{Absolute Advantage Theory (1776)}

The theory states that countries should produce only goods they have all the necessary facilities and technical know-how to manufacture. This means that the raw materials and factors of production needed for production are made available at a cheaper rate. This theory proposes that nations should produce and export only commodities over which they have absolute advantage in production, and they should import those over which they don't or have less absolute advantage.

\subsubsection{Hecksher Ohlin Trade Theory (H-O)}

This theory is also called two-by-two model, which means two goods, two factors of production and two countries. The difference in the availability of capital and labour (skill and unskilled) is one of the major reasons why countries trade between themselves. This theory is based on few assumptions; the two countries have identical taste and identical technology and different factor endowments. This theory opines that capital-abundant countries should export capital intensive goods and import labour intensive goods and vice versa. In buttressing the $\mathrm{H}-\mathrm{O}$ theory, Obi and Abina, (2018) pointed out that the availability of factors of production is a major determinant of price of commodity. The H-O theory brought about the Factor Price Equalization Theory (FPET) which states that internalization of factor prices will be attained as a result of same technology making the return to capital equal between the two countries.

\subsubsection{Economic Development Theory}

There have been several controversial issues arising as to which variable explains economic development. This controversy lies between the use of Gross Domestic Product (GDP), Gross National Product (GNP), Human Development Index (HDI) or Per Capita Income (PCI). It is a known fact that GDP and GNP measure goods and services produced in and outside the country, the two variables were eliminated because they cannot measure the fundamental things that economic development indicator signifies, whereas HDI and PCI measure the key fundamental attributes required for a nation to develop. The PCI and HDI measure citizen's life expectancy rate, educational attainment, and real income of an individual. An economy can be said to be developing when there is an upsurge in the rate of employment, reduction in poverty rate and an increase in the citizen's disposable income as it also captures the welfare of people in the country. All these arises due to changes in production and distribution of goods and services. 


\subsubsection{Lewis Theory of Development}

In the late 1950s, Arthur Lewis propounded the first economic development theory called the Lewis Theory of Development which was later modified by John Fei. This theory is based on a two-sector model, these two scenarios form the major plank in the Lewis development theory (Todaro \& Smith 2009). The theory assumes that there is zero marginal labour productivity (surplus labour) and the industrial sector which is highly productive. The industrial sector absorbs new labourers from the agricultural sector with the intention of compensating them with higher wages. The theory asserts that if this is done continuously, there will be increase in production and a reduction in the unemployment rate in the country. Lewis also posited that modern sector capital acquisition rate determines creation of employment opportunities, the theory also noted that in less developed countries, investment and savings are a major driver of economic development.

\subsection{Conceptual Review}

Figure 2.1 Diagram showing the Nigeria map with its neighboring states by the sides.

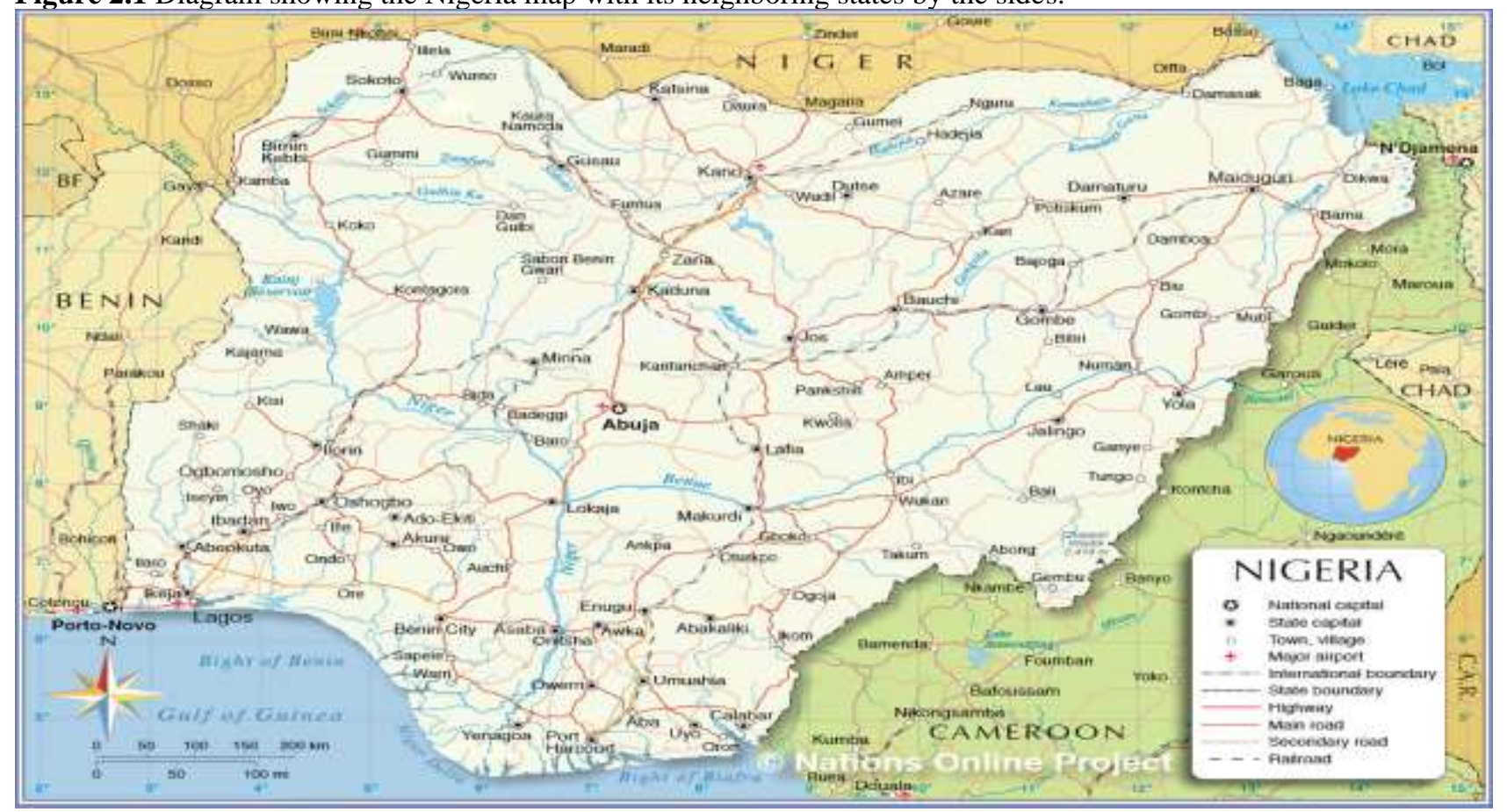

Source: Nations Online World Map

\subsubsection{Western Border of Nigeria}

The exact line that demarcates the border between the Republic of Nigeria and Republic of Benin seems unclear. Over time, the two countries have had very cordial, beneficial, and symbiotic historical records. This border was demarcated in the year 1889 linked with the western part of Nigeria by Lagos, Cotonou and Porto Novo. The border has a large lagoon called the Ouémé valley which is characterized with movement of merchandise by traders. The Ouémé valley is also noted with violence and illegal smuggling of harmful commodities in and out of Benin Republic to its neighboring Nigerian state.

Activities carried out at this border are vital to economic development in Nigeria as this border cuts across Lagos State which is reputed to be commercial capital of Nigeria. Prolonged closure of this border has the capacity to cripple and engender (inflation) economic activities between the countries. Benin Republic imports goods from European nations and channel them to Nigeria at a higher price. The informal trade that takes place in this border contributes tremendously to Beninoise GDP, Benin Republic witnessed some palpable panic in 2003 when the Olusegun Obasanjo's administration closed the border. Prior to this economic policy by the Nigerian government, some traders used this route to illegally smuggle petroleum products from Nigeria into Benin Republic.

\subsubsection{Eastern Border}

The Eastern part of Nigeria is bounded by Chad and Cameroon borders, while the Lake Chad border cut across the North Eastern part of Nigeria. Chad is a French and Arabic speaking nation. Nigeria and Chad have strong ties in international trade years after Chad was colonized by the French government, this happened because Nigeria became their major source of export revenue, replacing France. Both countries have consequently signed series of bilateral trade agreements. There was a dispute on Lake Chad between the two countries in the late 1970s when the island where oil was located became visible. This obligated the two member-states to agree to a territorial line that is more visible and backed by the United Nations. The Chadians export cattle, fish and chemicals into Nigeria 
while Nigeria exports crude oil and food stuff to Chad. Chad through the Lake Chad border was also used for smuggling foreign rice, people, drugs and small arms and light weapon (SALW) into Nigeria, this was done to evade import duty and legal documentation of goods. The trade ties started to deteriorate in the course of time because of insurgence which led to an intractable crisis along the borders of the two nations. Nigerians living in the North-Eastern part had to flee to neighboring countries because of Boko-Haram insurgence, making Nigerians to be refugees in the neighboring states. Chadian border was closed in 2014 and early 2015 due to the activities of the rebellious sect, the Ebola outbreak as well as the smuggling of drugs into the country.

\subsubsection{Northern Border}

Kebbi, Zamfara, Katsina and Sokoto are state that share boundary with Benin Republic in the Northern Part of Nigeria, an Islamic region of the county with predominantly Muslim population. It is also home to the Hausa and Fulani ethnic groups. Zamfara and Kebbi states were carved out of Sokoto state in 1991. Cattle rearing and agricultural activities are the two-major occupations in the area. Crops such as tomato, rice, beans, vegetable, sorghum, millet and onions are cultivated in large scale in the area due to its arable soil and natural endowment. Yobe state borders four of Nigeria's states of Jigawa, Bauchi, Gombe and Borno. This state shares boundary with the Republic of Niger. Yobe State was carved out of Borno State, located in the North East of Nigeria and shares border with three (3) African nations - Niger, Cameroon and Chad. Jigawa State has a free trade zone and it is located in the North Western region of Nigeria, it shares boundary with the Republic of Niger. This zone helps both the private traders and the government to trade efficiently. Goods exported to other contries via the border include foods items such as rice, tobacco etc while goods entering into the country through this border flank consists of chemicals and textile materials.

The militia use this route to smuggle different contraband items which are used in perpetuating their evil activities within the Nigerian territory. Some of these area have become den for armed robbers, smugglers, traffickers and sundry vices. The core northern part of Nigeria also cuts across the Sahara desert, an expansive and intolerable desert particularly noted for its dryness and drought which impedes agricultural activity.

\subsubsection{Southern Border of Nigeria}

In February 2014, the Southern border of Nigeria was closed in order to curtail the activities of rebellious sects. Cross River state located in the Southern part of Nigeria, shares boundary with Cameroon, a central West African francophone and anglophone country. The Cameroonian border also shares territorial border with North East of Chad. External trade that takes place in the region ranges from the exportation of vegetables, rubber, textile, clothing material, motor spare parts, food product, stone and glass, fuel and plastic, while goods imported include perfumes, cosmetics, toiletries, soaps, lubricants, wax, aluminum, coffee, tea, meat and spices, machineries, grain seed and modeling paste, etc. The major contention and disputation between both countries - Nigeria and Cameroon - in this region was the Bakassi Peninsula which is an oil-rich island. This dispute was settled by the International Court of Justice in 2002 where the court gave a verdict that the territory belongs to Cameroon and that Nigerians resident there were to seek residency permit since the case was won by Cameroon. The activities of Militants, Pirates, and Notorious Smugglers has made the southern border a dangerous route for movement of people, goods and services. The notorious activities of these sects have led to the death of citizens on both sides of the border which has caused a show of military strength over the years by both countries. Despite the presence of the military at the border, full and unrestricted smuggling of contraband items such as rice and illegal crude oil (fuel) is still in existence from Nigeria to Cameroon

\subsection{Empirical Review}

The foundation of Okunade's research (2017) was built on the human needs' theory, in which it was postulated that human action is tied to their needs, and that whenever there is an iota of displeasure the skirmish nature of the person surfaces. The study investigated two states (Ogun and Oyo) which is closer to the western boundary of Nigeria. The study made use of qualitative technique, prominent leaders were interviewed, and questionnaires were also administered. The study found out that border guards are not able to reach illegal routes in Oyo State because of their seemingly secret nature, and anytime they are opportune to discover these routes, criminals must have effectively utilized them for their illegal operation and devised another route. The study recommended that funds need to be made available for procurement of sophisticated equipment that will help to detect and track illegal activities ongoing on daily basis in the area. Sunday, Oji and Okechukwu, (2014) investigated how crimes affects national security in West Africa. The study drew deductions from several empirical works that the fundamental institution that propels growth is damaged as a result of the illegal and criminal activities that take place at the borders, making the growth process static, thereby hindering foreign direct investment. Adeyinka, (2014) examined how people boycott the lawful procedure in trans-border movement. It was discovered that Benin Republic border which is located at Idi-Iroko, Ogun state is largely porous because people bribe their way through. The study also argued that restriction to neighboring states might not be possible since communities in Africa are united culturally, traditionally, linguistically, ethnically, and even religiously. Thus, it was argued that there should be artificial restriction, especially the type foisted by the colonial masters in pre-independence Africa. The research work also 
reported that over $75 \%$ of traders who make use of this border transports their goods through the jungle, while $20 \%$ makes use of security officers as fronts. On the other hand, Blum, (2014) investigated the challenges Nigerians face in the southeastern part of the country. The study discovered that the link between development within Nigeria's borders is relatively low in comparison to development that takes place within the country itself. The fee traders bypass by bribing reduces revenue that ought to be generated and used for developing the nation. The establishment of the Joint Border Post (JBP) by the Republic of Benin and Nigeria have mitigated the frequent smuggling of Premium Motor Spirit (PMS) as well as arms importation. Duyile, (2014) critically examined The Hague "Bakassi Peninsula case." Having critically examined the dynamics of the historical problems, Duyile suggested two ways to settle the land dispute, one of which was that any of the two wings could be used to demarcate the boundary line. The study suggests that there is need to strategize, control and implement a wellstructured and intentioned policy that will help in checkmating countries that go against agreed truce. It was revealed that on several occasions the Cameroonian authority would remove the symbolic items used for demarcation between the two countries, including destroying economic trees, all these with the intention of claiming the territorial space, making people abandon their homes/villages, especially those residents in Taraba, Adamawa, Borno and Benue States respectively. Secondly, demarcation should be made very clear so as to make it very easy and possible for the law abiding/enforcement officers to report any activity that might arise to jeopardize the peace in Nigeria. Nuhu and Ishaku, (2015) investigated the Nigerian borders, security, and political development. The study made use of journals and historical records to draw logical conclusion. According to Nuhu and Ishaku, the quest for human want is insatiable which has led many people to be involved in unscrupulous transborder activities. Their work discovered that people lose their lives as a result of the militia activities in Nigeria, making a deductive conclusion that these activities can be mitigated if the security officials are provided with the best and sophisticated equipment.

\subsection{Research Methodology}

This research work focused on informal activities that takes place in the southeastern part of Nigeria, sharing boundary with the Republic of Cameroon to the East, Ebonyi State to the North West, Benue State to the North, Akwa Ibom State to the South, and Abia and Anambra State to the West. Thus, this research work used both the qualitative research design and purposive sampling technique which involves the use of questionnaire and oral interviews from officials that work around the borders - custom officers, marketers, taxi drivers, traders, travelers, students in tertiary institutions and others located around the borders.

\subsection{Sampling Size Determination}

Based on accessibility and convenience, this study made use of the purposive sampling technique. A total number of 101 personnel represents the target population which was drawn from six professions/skill sets.

The Yamene (1967) formula was used in determining the sample size viz:

Where,

$$
\Pi=\frac{N}{1+\left(N(e)^{2}\right.}
$$

$\mathrm{n}=$ Sample size

$\mathrm{N}=$ Population size

$\mathrm{e}=$ the error of sample at $5 \%$ or 0.05 level

$$
\Pi=\frac{101}{1+101(0.0025)}
$$

$\Pi=80.638$

The sample size is 81

Bowleys (1926) formula was used to ascertain the total number of questionnaires to be distributed to each professions/skill sets;

$$
n h=\frac{n N h}{N}
$$

Where; $\quad \mathrm{nh}=\quad$ The number of questionnaires for each professions/skill sets

$\mathrm{Nh}=\quad$ The number of employees in each professions/skill sets

$\mathrm{n}=\quad$ The total sample size 


$$
\mathrm{N}=\quad \text { The population. }
$$

Therefore, the number of questionnaires distributed to each target population is as shown in Table 3.1 below

Table 3.1:

Table 3.1:
\begin{tabular}{|c|l|c|c|}
\hline No. & \multicolumn{1}{|c|}{ Target Population } & Strength & Sample Size \\
\hline 1 & Trader & 17 & 14 \\
\hline 2 & Security Agent & 19 & 15 \\
\hline 3 & Transporter & 14 & 11 \\
\hline 4 & Student & 11 & 9 \\
\hline 5 & Business Men/Women & 22 & 18 \\
\hline 6 & Custom officer & 18 & 14 \\
\hline 7 & Others Sum & $\mathbf{1 0 1}$ & \\
\hline & \multicolumn{1}{|c|}{ Sum } \\
\hline
\end{tabular}

\subsection{Model Specification}

This research work was modeled based on the H-O, FPET and Lewis theory discussed above, which is built on the Likert scale (closed ended) questions. These questions allowed the qualitative measurement of the data for investigation, while there was a separate section to analyze the open-ended questions (oral questions). The below equation specifies the designed model based on theories above:

\section{Functional Model}

$\mathrm{PCI}=\mathbf{F}(\mathrm{CBT}, \mathrm{IFGE}, \mathrm{IFGM})$

Econometric Model

$\mathrm{PCI}_{\mathrm{t}}=\varphi_{\mathrm{o}}+\operatorname{CBT} \varphi_{1}+\operatorname{IFGE} \varphi_{2}+\operatorname{IFGM} \varphi_{3}+\mu_{\mathrm{i}}$

Apriori: $\varphi_{1}>0 \varphi_{2}<\varphi_{3}<0$.

Based on theories, the apriori expectation is formulated, it was modeled that CBT activity is meant to increase PCI $\left(\varphi_{1}>0\right)$ but IFGE and IFGM activity is mean to reduce PCI.

$\begin{array}{ll}\text { Key: } & \\ \text { PCI }= & \text { Per Capita Income } \\ \text { CBT }= & \text { Cross Border Trade } \\ \text { IFGE }= & \text { Informal Goods Exported } \\ \text { IFGM }= & \text { Informal Goods Imported } \\ \varphi_{\mathrm{o}}= & \text { Constant Parameter } \\ \varphi_{1-} \varphi_{3}= & \text { Estimated Parameter } \\ \mu_{\mathrm{i}}= & \quad \text { Error Term }\end{array}$

\subsection{Data Analysis Technique}

Descriptive analysis, multiple regression analysis and pearson product moment correlation coefficient analysis was used for data analysis. Deductive reasoning was also employed in analyzing different opinion obtained from the interview and different interactive sections.

\subsection{Data Analysis}

4.1 Analysis of Socio-Demographic Characteristics of Sample Respondents

The table below shows the demographic result of the questionnaire distributed to the target population for the purpose of this research work. 
Table 4.1

\begin{tabular}{|c|c|c|c|c|c|}
\hline \multicolumn{6}{|c|}{ Profession } \\
\hline & & Frequency & Percent & Valid Percent & $\begin{array}{c}\text { Cumulative } \\
\text { Percent }\end{array}$ \\
\hline \multirow[t]{7}{*}{ Valid } & Farmers & 14 & 17.3 & 17.3 & 17.3 \\
\hline & Government Officials & 15 & 18.5 & 18.5 & 35.8 \\
\hline & Drivers/Transporters & 11 & 13.6 & 13.6 & 49.4 \\
\hline & Students & 9 & 11.1 & 11.1 & 60.5 \\
\hline & Business Men/Women & 18 & 22.2 & 22.2 & 82.7 \\
\hline & Custom Officers & 14 & 17.3 & 17.3 & 100.0 \\
\hline & Total & 81 & 100.0 & 100.0 & \\
\hline
\end{tabular}

Source: Author's Field Survey (2020) - SPSS version 25 output

From the demographic result displayed in table 4.1 above, it can be seen that 14 persons which represent $17.3 \%$ of the respondents are into agricultural activities (farmers); 15 persons which represent $18.5 \%$ are government officials; 11 which represents $13.6 \%$ of respondents are into transportation business. 9 which represents $11.1 \%$ of the respondents are students, 18 persons which represent $22.2 \%$ of the respondent are business men/women and finally a total number of 14 persons which represent $17.3 \%$ of the respondent are customs officers, making a total of 81 persons that responded to the questionnaire.

Table 4.2: Respondents Distribution

\begin{tabular}{|c|c|c|c|c|c|}
\hline \multicolumn{6}{|c|}{ Age } \\
\hline & & Frequency & Percent & Valid Percent & Cumulative Percent \\
\hline \multirow[t]{4}{*}{ Valid } & $18-25$ & 32 & 39.5 & 39.5 & 39.5 \\
\hline & $26-35$ & 29 & 35.8 & 35.8 & 75.3 \\
\hline & $36-45$ & 20 & 24.7 & 24.7 & 100.0 \\
\hline & Total & 81 & 100.0 & 100.0 & \\
\hline
\end{tabular}

Source: Author's Field Survey (2020) - SPSS version 25 output

Table 4.2 indicates age distribution of the respondents; $39.5 \%$ of the respondents which is 32 persons are between ages $18-25$ years, $35.8 \%$ which is 29 persons are between the age of $26-35$, while $24.7 \%$ which represents 20 persons from the sample population are between age 36-45. In summary, majority of the persons that partook in the study are between the ages of 18-25 and 26-35 years.

Table 4.3

\begin{tabular}{|c|c|c|c|c|c|}
\hline \multicolumn{6}{|c|}{ Gender } \\
\hline & & Frequency & Percent & Valid Percent & Cumulative Percent \\
\hline \multirow[t]{3}{*}{ Valid } & Male & 46 & 56.8 & 56.8 & 56.8 \\
\hline & Female & 35 & 43.2 & 43.2 & 100.0 \\
\hline & Total & 81 & 100.0 & 100.0 & \\
\hline
\end{tabular}

Source: Author's Field Survey (2020) - SPSS version 25 output

Table 4.3 above represents the gender distribution of participants from the survey conducted. It indicates that 35 participants which is $43.2 \%$ are female while $56.8 \%$ that is 46 participants are male. Apparently, it can be concluded that most respondents in this study are male because of the nature of the business involved. 
Table 4.4

\begin{tabular}{|c|c|c|c|c|c|}
\hline & & \multirow[b]{2}{*}{ Frequency } & \multicolumn{3}{|l|}{ Marital Status } \\
\hline & & & Percent & Valid Percent & Cumulative Percent \\
\hline \multirow[t]{4}{*}{ Valid } & Single & 39 & 48.1 & 48.1 & 48.1 \\
\hline & Divorced & 5 & 6.2 & 6.2 & 54.3 \\
\hline & Married & 37 & 45.7 & 45.7 & 100.0 \\
\hline & Total & 81 & 100.0 & 100.0 & \\
\hline
\end{tabular}

Source: Author's Field Survey (2020) - SPSS version 25 output

Table 4.4 above represents the distribution of marital status of participants from the survey conducted. It was indicated that 5 participants which represent $6.2 \%$ of the sample respondents are divorced while 37 participants which is $45.7 \%$ are married, a total of 39 persons which represent $48.1 \%$ of the respondent are single. It can be concluded that most respondents in this study are single, the reason for this could be largely because this kind of trade require highly mobile persons who will not in any way be encumbered with family problems as this could affect the time and method of transacting business. The world of commerce is changing and dynamic such that it requires people who can adapt to this dynamism to transact business between themselves speedily.

Table 4.5

\begin{tabular}{|c|c|c|c|c|c|}
\hline \multicolumn{6}{|c|}{ Educational Background } \\
\hline & & Frequency & Percent & Valid Percent & $\begin{array}{c}\text { Cumulative } \\
\text { Percent }\end{array}$ \\
\hline \multirow[t]{8}{*}{ Valid } & No formal Education & 9 & 11.1 & 11.1 & 11.1 \\
\hline & Elementary Education & 11 & 13.6 & 13.6 & 24.7 \\
\hline & Secondary Education & 10 & 12.3 & 12.3 & 37.0 \\
\hline & National Diploma/NCE & 11 & 13.6 & 13.6 & 50.6 \\
\hline & Bachelors Degree/HND & 16 & 19.8 & 19.8 & 70.4 \\
\hline & $\begin{array}{l}\text { Master Degree } \\
\text { (M.Sc./MA/MBA) }\end{array}$ & 14 & 17.3 & 17.3 & 87.7 \\
\hline & Ph.D. & 10 & 12.3 & 12.3 & 100.0 \\
\hline & Total & 81 & 100.0 & 100.0 & \\
\hline
\end{tabular}

Source: Author's Field Survey (2020) - SPSS version 25 output

Table 4.5 above indicates participants' educational qualification which was categorized into seven different classes of which $11.1 \%$ ( 9 samples) have no formal education, 13.6\% which represents 11 persons are equipped with elementary education which aid them in transacting commercial activities; 10 persons which represent $12.3 \%$ have secondary school certificate; 11 persons which represent $13.6 \%$ have National Diploma/NCE; 14 of the respondents which represent $17.3 \%$ of the respondents are master's degree holders; 10 of the respondents representing $12.2 \%$ are holders of Ph.D degree. Clearly, bachelor's degree/HND holders dominate the categories considering their quota of $19.8 \%$ which represents 16 persons. 


\section{Table 4.6}

Table 4.6
\begin{tabular}{|llr|r|r|r|}
\hline \multicolumn{7}{|c|}{ My Business is Registered } \\
& \multicolumn{1}{c|}{ Frequency } & Percent & Valid Percent & Cumulative Percent \\
\hline Valid & Yes & 47 & 58.0 & 58.8 & 58.8 \\
\cline { 2 - 6 } & No & 33 & 40.7 & 100.0 & 100.0 \\
\hline & Total & 80 & 98.8 & \\
\hline Missing & System & 1 & 1.2 & \\
\hline Total & & 81 & 100.0 & & \\
\hline
\end{tabular}

Source: Author's Field Survey (2020) - SPSS version 25 output

To ascertain the legal status of business operatives that carry out various activities at the border within the southeastern part of Nigeria, there is need to know if the business is registered or not. From the above table 4.6, we can logically deduce that $58.0 \%$ which represents 47 persons of the sample population have fully registered their business whereas $40.7 \%$ representing 33 respondents have not fully registered their business. Response from a few of the respondents in an interview on why they have not fully incorporated their business, it was reported that the criteria and time to incorporate the business was quite intolerably long and the kickbacks required to expedite such process was high enough to start another business on its own.

Table 4.6

\begin{tabular}{|c|c|c|c|c|c|}
\hline \multicolumn{6}{|c|}{ I Am into } \\
\hline & & Frequency & Percent & Valid Percent & $\begin{array}{c}\text { Cumulative } \\
\text { Percent }\end{array}$ \\
\hline \multirow[t]{5}{*}{ Valid } & Exportation & 27 & 33.3 & 33.3 & 33.3 \\
\hline & Importation & 45 & 55.6 & 55.6 & 88.9 \\
\hline & Both Importation and Exportation & 5 & 6.2 & 6.2 & 95.1 \\
\hline & None & 4 & 4.9 & 4.9 & 100.0 \\
\hline & Total & 81 & 100.0 & 100.0 & \\
\hline
\end{tabular}

Source: Author's Field Survey (2020) - SPSS version 25 output

Because of the area and the nature of our target population, there is need to know if the respondent is either into importation/exportation of goods/services or not. From the survey result in table 4,6 above it was discovered that 45 persons which represents $55.6 \%$ of the respondents are into importation of one commodity or the other whereas 27 persons which represents $33.3 \%$ of the respondent are into exportation, while $4.9 \%$ which represents 4 persons from the sampled population are neither into importation nor exportation of goods and services. 
Table 4.7

\begin{tabular}{|c|c|c|c|c|c|}
\hline \multicolumn{6}{|c|}{ What kind of business do you engage in } \\
\hline & & Frequency & Percent & Valid Percent & $\begin{array}{c}\text { Cumulative } \\
\text { Percent } \\
\end{array}$ \\
\hline \multirow[t]{13}{*}{ Valid } & Food Item & 7 & 8.6 & 8.6 & 8.6 \\
\hline & Car & 17 & 21.0 & 21.0 & 29.6 \\
\hline & Agriculture Product & 3 & 3.7 & 3.7 & 33.3 \\
\hline & Crude Oil & 11 & 13.6 & 13.6 & 46.9 \\
\hline & Heavy Duty Machine & 3 & 3.7 & 3.7 & 50.6 \\
\hline & Clothing & 5 & 6.2 & 6.2 & 56.8 \\
\hline & Petty Trade & 4 & 4.9 & 4.9 & 61.7 \\
\hline & Construction Related Goods & 2 & 2.5 & 2.5 & 64.2 \\
\hline & Electronic Equipment & 12 & 14.8 & 14.8 & 79.0 \\
\hline & Furniture Supply & 8 & 9.9 & 9.9 & 88.9 \\
\hline & Laboratory/ Pharmacy & 4 & 4.9 & 4.9 & 93.8 \\
\hline & Plastics & 5 & 6.2 & 6.2 & 100.0 \\
\hline & Total & 81 & 100.0 & 100.0 & \\
\hline
\end{tabular}

Source: Author's Field Survey (2020) - SPSS version 25 output

From the survey result above it was discovered that seven (7) persons who participated in the survey are into food item business; a total of 17 persons are into car business which represents about $21.0 \%$ of the sampled population; $3.7 \%$ is into agricultural product; $13.6 \%$ which represents 11 persons from the sampled respondent are into exportation of crude oil; 3 persons which represents $3.7 \%$ are into the business of heavy-duty machine. Due to the area of this research work it is easy for electronic item and clothing item to be transported via the sea into the country; $6.2 \%$ which represents 5 of the respondents are into clothing business; $4.9 \%$ of the sample respondents are into petty trade business; $2.5 \%$ of the respondents are into construction related business. $14.8 \%$ of the respondents are into electronic related business; $9.9 \%$ of the respondents are into furniture supplies; 4 persons which represents $4.9 \%$ are into laboratory/pharmacy, $6.2 \%$ which represents 5 of the respondents are into plastic business.

Table 4.8

\begin{tabular}{|c|c|c|c|c|c|}
\hline \multicolumn{6}{|c|}{ How Long Have You Been in Business? } \\
\hline & & Frequency & Percent & Valid Percent & Cumulative Percent \\
\hline \multirow[t]{3}{*}{ Valid } & $1-5$ years & 31 & 38.3 & 38.8 & 38.8 \\
\hline & Over 5years & 49 & 60.5 & 61.3 & 100.0 \\
\hline & Total & 80 & 98.8 & 100.0 & \\
\hline Missing & System & 1 & 1.2 & & \\
\hline Total & & 81 & 100.0 & & \\
\hline
\end{tabular}

Source: Author's Field Survey (2020) - SPSS version 25 output

The validity of this research work is not complete until it ascertains the duration of period in terms of years respondents have been in business. From the result above, we can deduce that 49 persons have been into their respective businesses for over five years while 31 persons have been in business for between 1 year and 5years as at the time the survey was taken. 


\subsection{Bivariate Analysis}

\section{Universal Model Evaluation}

To observe how fitted the employed variables are, the study starts by evaluating the interplay of the employed dimensions and measures of the study variables as follows.

Table 4.9

\begin{tabular}{|c|c|c|c|c|}
\hline & & Model S & mmary & \\
\hline Model & $\mathrm{R}$ & R Square & $\begin{array}{c}\text { Adjusted R } \\
\text { Square }\end{array}$ & $\begin{array}{l}\text { Std. Error of } \\
\text { the Estimate }\end{array}$ \\
\hline 1 & $.942^{\mathrm{a}}$ & .888 & .883 & .34258732 \\
\hline
\end{tabular}

Source: SPSS Version 25 Output.

Table 4.10

\begin{tabular}{|c|c|c|c|c|c|c|}
\hline \multicolumn{7}{|c|}{ ANOVA $^{a}$} \\
\hline & & Sum of Squares & $\mathrm{df}$ & Mean Square & $\mathrm{F}$ & Sig. \\
\hline \multirow[t]{3}{*}{1} & Regression & 63.019 & 3 & 21.006 & 178.982 & $.000^{\mathrm{b}}$ \\
\hline & Residual & 7.981 & 68 & .117 & & \\
\hline & Total & 71.000 & 71 & & & \\
\hline
\end{tabular}

Source: SPSS Version 25 Output.

The study observed from Table 4.9 that the R-square value of 0.888 shows that all the employed dimensions of informal goods imported, cross-border trade and informal goods exported jointly account for up to 88.8 percent of variation in the criterion variable as captured in the above by per capita income. This shows that the variables used to predict the behavior of informal cross-border trade are adequate predictors of the variables. As such, this shows that the variables were well selected. The F-statistics value of 178.982 at a significance level of 0.000 which is lower than the 0.05 significance shows that the model is well fitted. This means that the employed variables go hand-in-hand and as such are well blended.

Table 4.11 Multiple Regression Analysis

\begin{tabular}{|c|c|c|c|c|c|c|}
\hline \multicolumn{7}{|c|}{ Coefficients $^{\mathrm{a}}$} \\
\hline \multirow{2}{*}{\multicolumn{2}{|c|}{ Model }} & \multicolumn{2}{|c|}{ Unstandardized Coefficients } & \multirow{2}{*}{$\begin{array}{c}\text { Standardized } \\
\text { Coefficients } \\
\text { Beta }\end{array}$} & \multirow[b]{2}{*}{$\mathrm{t}$} & \multirow[b]{2}{*}{ Sig. } \\
\hline & & $\mathrm{B}$ & Std. Error & & & \\
\hline \multirow[t]{4}{*}{1} & (Constant) & $-1.770 \mathrm{E}-17$ & .040 & & .000 & 1.000 \\
\hline & Cross Border Trade & .940 & .041 & .940 & 23.075 & .000 \\
\hline & Informal Goods exported & -.004 & .044 & .004 & .100 & .921 \\
\hline & Informal Goods Imported & -.045 & .044 & -.045 & -1.023 & .310 \\
\hline
\end{tabular}

Source: Source: SPSS Version 25 Output.

It was discovered that cross-border trade has a positive and significant relationship with per capita income whereas informal goods exported has a positive and insignificant relationship with per capita income and finally informal goods imported exhibit a negative with an insignificant relationship with per capita income. Thus, a unit increase in cross-border trade and informal goods exported will lead to an increase of about 0.940 and 0.004 in per capita income respectively but a unit increase in informal goods exported will lead to about 0.004 unit decrease in per 
capita income, but a unit increase in informal goods imported leads to a reduction of about $-0.045 \%$ in per capita income in the country.

\subsection{Test of Research Hypotheses}

The study proceeds to test for research hypothesis in light of the Pearson product moment and multiple regression analysis as follows.

\section{Hypothesis One}

H01: Significant relationship does not exist between cross-border trade and per capita income in Nigeria.

Table 4.12 Pearson Correlation Test on $\mathrm{HO}_{1}$

\begin{tabular}{|llr|r|}
\hline \multicolumn{1}{c|}{ Correlations } & \multicolumn{1}{c|}{ Cross Border } \\
& \multicolumn{1}{c|}{ Trade } & Per Capita Income \\
\hline Cross Border Trade & Pearson Correlation & 1 & $.941^{* *}$ \\
\cline { 2 - 4 } & Sig. (2-tailed) & 72 & .000 \\
\cline { 2 - 4 } & $\mathrm{N}$ & $.941^{* *}$ & 72 \\
\hline Per Capita Income & Pearson Correlation & .000 & 1 \\
\cline { 2 - 4 } & Sig. (2-tailed) & 72 & 72 \\
\cline { 2 - 4 } & $\mathrm{N}$ & & \\
\hline **. Correlation is significant at the 0.01 level (2-tailed). & & \\
\hline
\end{tabular}

Source: Author's Field Survey (2020)- SPSS Version 25 Output

From the result of the Pearson correlation analysis in Table 4.12 above, it can be seen that cross-border trade (CBT) has a positive (Co-efficient value of 0.941) and significant relationship ( $\mathrm{P}$-value of 0.000) with per capita income (PCI). Thus, for every one unit increase in CBT, it will lead to about 0.941 unit increase in PCI, the result accept our earlier apriori expectation earlier stated in the model and as such the null hypothesis will be rejected while the alternate hypothesis will be accepted, cross border trade exposes trade countries to technological transfer, increased market share and job opportunities, CBT has helped merchants in exposing their business activity across their local geographical boundary which increases their market share, sustainability and access to increase customers on the long run.

CBT has helped merchants gain access to international market which has increased revenue base of merchants as they get larger customer base to cater for, which consequently, amplifies sales at little or no cost. Merchants are exposed to a wide range of product diversification as they use the opportunity of international bodies to sell their low demand product in the home market to foreign market as this will mitigate the risk attached to goods staying too long in the warehouse which might eventually result in total loss. The standard of living of the merchants increases as a result of the additional market which increased their revenue base. The federal government of Nigeria is not left out as they also make money from international transaction in terms of custom duties (import and export) and fines levied on offenders.

\section{Hypothesis Two}

H02: Significant relationship does not exist between illegal goods leaving (exported) the home country and per capita income in Nigeria. 
Table 4.13 Pearson Correlation Test on $\mathrm{HO}_{2}$

\begin{tabular}{|c|c|c|c|}
\hline \multicolumn{4}{|c|}{ Correlations } \\
\hline & & $\begin{array}{c}\text { Informal Goods } \\
\text { Exported } \\
\end{array}$ & Per Capita Income \\
\hline \multirow[t]{3}{*}{ Informal Goods Exported } & Pearson Correlation & 1 & -.077 \\
\hline & Sig. (2-tailed) & & .521 \\
\hline & $\mathrm{N}$ & 72 & 72 \\
\hline \multirow[t]{3}{*}{ Per Capita Income } & Pearson Correlation & -.077 & 1 \\
\hline & Sig. (2-tailed) & .521 & \\
\hline & $\mathrm{N}$ & 72 & 72 \\
\hline
\end{tabular}

Source: Author's Field Survey (2020)- SPSS Version 25 Output

From the result in Table 4.13 above, it can be seen that Informal Goods Exported (IFGE) has a negative (coefficient value of -0.077) with an insignificant (P-value of 0.521) relationship with per capita income (PCI), this means for every one unit increase in IFGE, it will lead to about -0.077 unit decrease in PCI therefore the study can accept the null hypothesis having discovered that the p-value is greater than $0.05 \%$ significance level thus, our apriori expectation will be rejected since its contributing negatively to PCI. It was deduced from oral investigation that informal trade increases disposable income and lifestyle of merchants on the short run but on the long run they go back to their lifestyle before that.

\section{Hypothesis Three}

H03: Significant relationship does not exist between informal goods (imported) into the home country and per capita income in Nigeria.

Table 4.14 Pearson Correlation Test on $\mathrm{HO}_{3}$

Table 4.14 Pearson Correlation Test on $\mathrm{HO}_{3}$
\begin{tabular}{|llr|r|}
\hline \multicolumn{1}{|c|}{ Correlations } & $\begin{array}{c}\text { Informal Goods } \\
\text { Imported }\end{array}$ & \multicolumn{1}{c|}{$\begin{array}{c}\text { Per Capita } \\
\text { Income }\end{array}$} \\
\hline $\begin{array}{l}\text { Informal Goods } \\
\text { Imported }\end{array}$ & Pearson Correlation & 1 & -.065 \\
\cline { 2 - 4 } & Sig. (2-tailed) & 72 & .589 \\
\hline Per Capita Income & $\mathrm{N}$ & -.065 & 72 \\
\hline & Pearson Correlation & .589 & 1 \\
\hline & Sig. (2-tailed) & 72 & 72 \\
\hline
\end{tabular}

Source: Author's Field Survey (2020)- SPSS Version 25 Output

From the result in Table 4.14 above it can be deduced that Informal goods imported (IFGM) has a negative (coefficient value of -0.065) with an insignificant relationship (probability value of 0.589 ) with per capita income thus, for every one percent increase in IFGM, there will be a reduction of about $-0.065 \%$ in per capita income. Our apriori expectation earlier stated will be rejected, since there is a negative contribution to PCI identified. From the oral interview, it was deduced that the informal goods imported have a way of making the economy retrogress as they surcharge what the government should be gaining (income generated from import duty) for private pocket of custom officers.

\subsection{Conclusion and Recommendation}

From the survey carried out, we can logically deduce that cross-border trade has a positive and significant relationship with per capita income in Nigeria. This means trade between Nigeria and its neighboring country increases standard of living of the people. The result from the survey also shows that informal goods exported/imported has a negative relationship with standard of living of people in Nigeria. From the regression analysis result and the oral interview section, it was deductively concluded that the economic consequence of informal cross border trade in Nigeria is very grievous as it has negative consequences on the value of Naira. The value of the Naira is affected (fluctuate) by informal cross border trade because the monies involved are not 
accounted for by the recognized financial systems in the two-trading countries. The receiving country becomes the dumping site as they retrogress in technology and innovation, the social stability of the receiving countries' fiscal and monetary policies will be hampered as the country might not be able to meet proposed revenue projections. In the year 2020, it was reported that informal goods entering the country (Nigeria) doubled due to border closure which took effect in August 2019 almost immediately after signing the Africa Continental Free Trade Area Agreement (AFCTA). The closure was primarily for the purpose of safeguarding food supply in the country and preventing smuggling activities within the boundary area. The study also pointed out that persons and countries that indulge in informal trade makes it difficult for small scale industries to measure up to international standard, and also difficult for competition to take place between two trading nations.

This study therefore recommends that there is a need for government to investigate and review the lists of frequently smuggled items into Nigeria and respond by developing incentive policies to encourage local production of such items and use regulatory polices to enforce the ban on such items from being imported. The government must adopt an $100 \%$ e-payment system for duties so as to eliminate the exchange of cash between traders and officials (Custom, Police, Immigration) at the border post, this will reduce the incident of bribery and boost the revenue of government. Government must streamline payment and goods clearing systems at the borders to be real time as delays at the borders is one of the primary reasons why informal trade in perishable goods such as food materials continues to thrive. The government should register and profile importers and exporters for the purpose of extending discounts, rebates, and waivers to them from time to time based on their transaction history, this will discourage informal cross border trade to a large extent. Frequent transfer of officers (Customs, Police, and Immigration) out of the border posts as well as enhanced compensation system for the serving officers. Finally, there must be robust enlightenment programs aimed at encouraging informal cross border traders to go through the right channel in importing and exporting goods, a whistle blowing system should also be set up for people to report incidence of bribery, abuse and neglect of laid down policies in all borders in the country while providing a reward system to encourage genuine whistleblowers.

\section{References}

Adeola, G. L, \& Oluyemi, F. (2012). The political and security implications of cross border migration between Nigeria and her francophone neighbors. International Journal of Social Science Tomorrow, 3(1), 1-10.

Adeyinka, A.M. (2014). Trans-border movement and trading activities across Nigeria- Benin Republic Border. Mediterranean Journal of Social Sciences, 1(5), 415- 423.

Afrika, J-G, K., \& Ajumbo, G. (2012). Informal cross border trade in Africa: Implications and policy recommendations, African Economic Brief, AfDB, 10(3),8

Babatola, J.E.T. (2012). Nigerian-Cameroon boundary dispute: The Quest for Bakassi Peninsular. Journal of International Affairs and Global Strategy. 1(4), 81-95.

Babatola, J.E.T. (2015). Challenges of Nigeria borders and frontier security. Retrieved from https://www.researchgate.net/publication/313860814.

Blum, C. (2014) Cross-border flows between Nigeria and Benin: What are the challenges for (human) security? Abuja: Friedrich-Ebert-Stiftung Regional Office, - (FES peace and security series. Retrieved from http://www.bit.ly/3apRsfW.

Bowley, A. L. (1926). Measurement of the precision attained in sampling. Bulletin of The International Statistical Institute, Supplement to Liv. 1, (22), 6-62.

CBN (2016). Measuring informal cross-border trade in Nigeria. Retrieved from http://www.bit.ly/3tphoBd.

Duyile, A. (2014). Nigeria-Cameroon boundary relations in the North of Nigeria, 1914- 94. International Affairs and Global Strategy. ISSN 2224-574X (Paper) ISSN 2224-8951 (Online). 1(27), 35-39.

Edogun, H. A., Daramola, G. O., Esan C. O., \& Edungbola, I. D. (2017). Prevalence of malaria parasitaemia in three selected local government areas of Niger State, North Central, Nigeria. Journal of Advances in Biology \& Biotechnology, (3)16, 1-9. DOI: 10.9734/JABB/2017/37884

Kabira, W. M. (2006). Women and cross border trade in East Africa. Retrieved from https://www.library.fes.de. Matsuyama, R. (2011). Risky business of informal cross border trade. Retrieved from https://www. Afronews.com. Nte, N.D. (2011). The changing patterns of small and light weapons (SALW) proliferation and the challenges of national security in Nigeria. Global Journal of Africa Studies, 1(1), 5-23.

Nuhu, M., \& Ishaku, H. (2015). Developing Nigeria's border paradigm: The panacea for national security, socioeconomic and political development. Developing Country Studies, 21(5), 154-161 ISSN 2224-607X (Paper) ISSN 2225-0565 (Online). 
Obi, E., \& Abina, P.A (2018). Protectionism and development of an emerging economy. Journal of Contemporary Research, 6(2),243-253

OECD. (2009). Informal cross border trade in Africa. OECD publication. www.oecd.org/trade.

Okunade, S.K (2017) Perspectives on illegal routes in Nigeria. International Association of African Researchers and Reviewers. 11(2), 14-24. DOI : http://dx.doi.org/10.4314/afrrev.v11i2.2

Organization of Economic Cooperation and Development (OECD) (2009). Informal cross border trade in Africa. OECD publication. Retrieved from https://www.oecd.org/trade

Ricardo, D. (1817). The theory of comparative advantage. Library of economics and liberty. Retrieved from; http://www. econlib. org/library/Enc/bios/Ricardo. html.

Samuelson, P., \& Nordhaus, W. (1995). Economics. New York: McGraw-Hill

Soderbaum, F., \& Taylor, I. (2008). The dynamics of cross border micro regionalism in Africa. (Ed) Nordiska Africa Institute.

Sunday, O.V., Oji, O., \& Okechukwu, R. (2014). Cross border crimes in West African Sub- Region: implications for Nigeria's national security and external relations Global Journal of Human-Social Science: (F). Political Science, 3(14).45-57. Online ISSN: 2249-460x.

Todaro. P., \& Smith, C. (2009). Economic development. Tenth edition. Published by Pesrdons Education Limited. Edinburgh Gate, Harlow Essex CM 20 2JE, England. ISBN: 978-1-4058-7424-3.

United Nations Conference on Trade and Development (UNCTAD) (2011). Who Is benefiting from trade liberalization in Cape Verde? A gender perspective. Geneva: United Nations.

United Nations Conference on Trade and Development (UNCTAD) (2019). Trade and development Report. Financing a global green new deal. UNCTAD/TDR/2019 (Overview).

World Bank (2006). Global economic prospects: Economic implications of remittances and migration. Washington, D.C.

World Bank (2010). World trade indicators 2009/10. Retrieved from http://www.worldbank. org/wti.

Yamane, T. (1967). Statistics, An Introductory Analysis, 2nd Ed., New York: Harper and Row.

Yusuff, S.O (2014). Gender dimensions of informal cross border trade in West-African Sub-Region (ECOWAS) borders. International Letters of Social and Humanistic Sciences, (29),19-33. doi:10.18052/www.scipress.com/ILSHS.29.19. 